\title{
Analisis Margin dan Efisiensi Pemasaran Ikan Bandeng dan Ikan Tongkol di DKI Jakarta \\ (Analysis Marketing Margin and Efficiency of Milkfish and Mackarel Tuna Fish at DKI Jakarta) \\ D Iwan Riswandi ${ }^{1}$ dan Wawan Oktariza ${ }^{2}$
}

${ }^{1}$ Program Diploma IPB, Kampus Cilibende - Bogor, ${ }^{2}$ Departemen PSP, FPIK IPB, Kampus IPB Darmaga Bogor. Korespondensi wawanoktariza@yahoo.com

Diterima/disetujui : 18 Juni 2015/ 25 Juni 2015

\begin{abstract}
Ministry of Marine Affairs and Fisheries has continued to roll out policies for the empowerment of fisherman and fish farmers, especially the micro scale. In order to enhance the welfare and income of fish farmers and fisherman, the problems in marketing that need to be getting the attention that is associated marketing margin and efficiency of capture fisheries and aquaculture commodity. The purpose of this study is to analyze marketing margin and efficiency of milkfish and mackarel tuna coming into Jakarta market as well as provide marketing policy recommendations of fishery products. The results showed that the marketing of milkfish and mackarel tuna to the Jakarta market based on marketing costs have been efficient because the costs are relatively low compared to the price of the consumer level. However, based on marketing cost-benefit ratio is not efficient because it can not hold a fair sharing of the overall price paid by the consumers to producers and middleman involved in the production and marketing of the commodity. Therefore, there needs to be marketing regulation to protect the interests of fish farmers, fisherman and consumers in the marketing of fishery commodities.
\end{abstract}

Keyword: marketing efficiency, milkfish and mackarel tuna, marketing regulation

\section{PENDAHULUAN}

Pembangunan kelautan dan perikanan dalam lima tahun kedepan (2015-2019) diarahkan untuk memenuhi tiga pilar yang saling terintegrasi, yakni kedaulatan (sovereignty), keberlanjutan (sustainability), dan kemakmuran (prosperity). Hal ini dilakukan guna terwujudnya pengelolaan sumberdaya kelautan dan perikanan secara berdaulat, mandiri dan berkelanjutan untuk kemakmuran rakyat.

Kementerian Kelautan dan Perikanan (KKP) terus berupaya menggulirkan kebijakan-kebijakan untuk pemberdayaan nelayan dan pembudidaya ikan khususnya yang berskala mikro. KKP saat ini tengah menyusun Rancangan Peraturan Pemerintah (RPP) tentang Pemberdayaan Nelayan Kecil dan Pembudidaya-Ikan Kecil. Peraturan ini selain untuk memberdayakan juga untuk melindungi nelayan dan pembudidaya ikan kecil yang menjadi sasaran dan prioritas program pro rakyat KKP.

Pada sektor perikanan budidaya, KKP saat ini fokus terhadap kegiatan peningkatan produksi dengan melakukan upaya mereduksi biaya input produksi sehingga diharapkan dapat berimplikasi terhadap peningkatan pendapatan dan keuntungan pembudidaya ikan. Sedang pada sektor perikanan tangkap, KKP telah menggulirkan kebijakan-kebijakan dan kegiatan dalam rangka mensejahterakan para nelayan agar pendapatan meningkat, sehingga tidak lagi menjadi profesi yang termarginalkan.

Dalam rangka mewujudkan peningkatan kesejahteraan serta pendapatan pembudidaya ikan dan nelayan yang merupakan salah satu fokus pembangunan pro 
rakyat, maka permasalahan-permasalahan di bidang pemasaran yang perlu segera mendapatkan perhatian yaitu terkait efisiensi dan margin pemasaran komoditas perikanan budidaya maupun perikanan tangkap. Nelayan dan pembudidaya ikan selama ini memiliki posisi tawar yang rendah dibandingkan dengan pedagang perantara yang memiliki informasi pasar. Posisi tawar kuat yang dimiliki oleh pedagang perantara tersebut mempengaruhi margin ditingkat nelayan dan pembudidaya ikan, yang pada akhirnya mempengaruhi keuntungan yang diterima oleh pedagang perantara dan nelayan/pembudidaya ikan. Semakin besar selisih harga ditingkat pembudidaya atau nelayan dengan harga yang dibayarkan konsumen akhir menjadi indikasi semakin tidak efisiennya saluran pemasaran dan semakin sedikit bagian yang diterima oleh pembudidaya atau nelayan (farmer's share/fisherman'share).

Sehubungan dengan permasalahan diatas maka penulis tertarik untuk mengkaji pemasaran komoditas perikanan hasil budidaya maupun perikanan tangkap di DKI Jakarta. Sebagai sampel dari komoditias hasil budidaya dipilih komoditas ikan bandeng dan sampel komoditas perikanan tangkap dipilih komoditas ikan tongkol. Alasan pemilihan kedua komoditas tersebut yaitu merupakan komoditas yang dominan di pasar yang ada di DKI Jakarta. Hal ini dilakukan untuk mengidentifikasi permasalahan secara detail dan menyeluruh guna memberikan rekomendasi kebijakan dibidang pemasaran. Tujuan penelitian ini yaitu menganalisis margin dan efisiensi pemasaran ikan bandeng dan tongkol yang masuk ke DKI Jakarta serta memberikan rekomendasi kebijakan pemasaran hasil perikanan.

\section{Waktu dan Tempat}

\section{METODOLOGI}

Penelitian dilaksanakan pada bulan Juli - September 2015. Penelitian dilaksanakan di Pelabuhan Ratu - Kabupaten Sukabumi, Kabupaten Indramayu dan Provinsi DKI Jakarta. Pelabuhan Ratu - Kabupaten Sukabumi sebagai sumber produksi ikan tongkol, Kabupaten Indramayu sebagai sumber produksi ikan bandeng, dan Provinsi DKI Jakarta sebagai daerah tujuan pemasaran ikan bandeng dan ikan tongkol.

\section{Metode Penelitian}

Metode penelitian yang digunakan yaitu penelitian survei. Metode survei adalah penelitian yang diadakan untuk memperoleh fakta-fakta dari gejala yang ada dan mencari keterangan secara faktual, baik tentang institusi, sosial, ekonomi, atau politik dari suatu kelompok atau suatu daerah (Nazir 2003). Pengumpulan data primer dilakukan dengan melakukan wawancara dengan menggunakan kuesioner dengan para pelaku pemasaran. Data sekunder dikumpulkan dari beberapa sumber seperti Kementerian Kelautan dan Perikanan, Dinas Kelautan dan Perikanan Kabupaten, dan Pelabuhan Perikanan Nusantara Pelabuhan Ratu.

Penetapan responden menggunakan metode non probability sampling yaitu purposive (Supranto 1977). Alasan penggunaan metode tersebut yaitu untuk mendapatkan sampel yang sesuai dengan tujuan penelitian yaitu pedagang perantara yang memasarkan ikan bandeng dari Indramayu dan ikan tongkol dari Pelabuhan Ratu ke pasar Jakarta. Responden terdiri dari nelayan yang menangkap ikan tongkol, pembudidaya bandeng, pedagang pengumpul, pedagang pengumpul besar, pedagang grosir, dan pedagang pengecer. 


\section{Analisis data}

\section{Analisis marjin pemasaran}

Marjin pemasaran adalah perbedaan harga yang dibayar kepada produsen dan harga yang dibayar konsumen (Saefudin dan Hanafiah 1986). Perhitungan analisis marjin pemasaran dilakukan untuk mengetahui perbedaan harga per satuan tingkat produsen atau tingkat konsumen yang terjadi pada rantai pemasaran (Sudiyono 2001). Rumus yang digunakan :

$M_{i}=H K_{i}-H P_{i}$

dimana: $\quad M_{i}=$ Marjin pemasaran pasar tingkat ke-i

$\mathrm{HK}_{\mathrm{i}}=$ Harga beli konsumen tingkat ke-i

$\mathrm{HP}_{\mathrm{i}}=$ harga jual produsen ke-i

Margin pemasaran juga dapat diperoleh dengan menjumlah biaya pemasaran dan keuntungan setiap lembaga yang terlibat dalam pemasaran. Rumus yang digunakan :

$M_{i}=C_{i}+\pi_{i}$

dimana : $\quad \mathrm{Ci}=$ biaya pemasaran lembaga ditingkat ke-i

$\Pi \mathrm{i}=$ keuntungan pemasaran lembaga ditingkat ke-i

\section{Analisis efisiensi pemasaran}

Analisis ini digunakan untuk mengukur tingkat efisiensi pemasaran pada setiap lembaga pemasaran yang terlibat. Menurut Soekartawi (2002) rumus efisiensi pemasaran yaitu :

Eps $=\frac{B P}{H E} \times 100 \%$

Dimana : $\quad$ Eps $=$ Efisiensi pemasaran

$$
\begin{aligned}
& \mathrm{BP}=\text { Biaya pemasaran } \\
& \mathrm{HE}=\text { Harga eceran (ditingkat konsumen akhir) }
\end{aligned}
$$

\section{Analisis rasio keuntungan - biaya}

Analisis ini digunakan untuk mengetahui penyebaran rasio keuntungan - biaya pada masing-masing lembaga pemasaran serta untuk mengetahui tingkat efisiensi sistim pemasaran. Menurut Limbong dan Sitorus (1987) rumus rasio keuntungan - biaya yaitu :

Rasio keuntungan - biaya $=\frac{\text { Keuntungan }}{\text { Biaya pemasaran }} \times 100 \%$

\section{Analisis Farmer's share atau Fisherman's Share}

Analisis ini digunakan untuk membandingkan harga yang diterima produsen dengan harga yang dibayarkan oleh konsumen akhir (Limbong dan Sitorus 1987). Rumus yang digunakan :

$$
\begin{aligned}
& \text { Fs }=\frac{P f}{P r} \times 100 \% \\
& \text { dimana }: \begin{array}{l}
\text { Fs } \\
=\text { farmer's share atau fisherman's share } \\
\mathrm{Pf}=\text { harga ditingkat pembudidaya ikan/nelayan } \\
\operatorname{Pr}=\text { harga ditingkat konsumen akhir }
\end{array}
\end{aligned}
$$




\section{HASIL DAN PEMBAHASAN}

Hasil perikanan sebelum sampai ditangan konsumen akhir, yang akan mengkonsumsi ikan, memerlukan serangkaian kegiatan yang meliputi : produksi, pengumpulan informasi, sortasi dan grading, pengangkutan, pengumpulan, penyimpanan, promosi dan penjualan. Dalam pemasaran suatu produk atau komoditas, menurut Limbong dan Sitorus (1987) terdapat tiga kelompok yang secara langsung terlibat yaitu 1) produsen; 2) lembaga perantara; dan 3) konsumen akhir Dalam bidang perikanan yang termasuk kelompok produsen terdiri dari nelayan dan pembudidaya ikan. Lembaga perantara dalam bidang perikanan terdiri dari pedagang pengumpul lokal, pedagang pengumpul antar kota, pedagang besar, pedagang pengecer, dan pasar lembaga. Konsumen akhir merupakan pihak yang langsung menggunakan atau mengkonsumsi barang dan jasa.

Saluran pemasaran produk atau komoditas bisa panjang atau pendek. Panjangpendeknya saluran pemasaran hasil perikanan menurut Hanafiah dan Saefudin (1986) dipengaruhi oleh beberapa faktor yaitu :

a) Jarak antara produsen dan konsumen; semakin jauh jarak antara produsen dan konsumen biasanya saluran pemasaran produk akan semakin panjang.

b) Cepat tidaknya produk rusak; produk yang cepat atau mudah rusak harus segera diterima oleh konsumen, sehingga menghendaki saluran yang pendek dan cepat.

c) Skala produksi; apabila skala produksi dalam ukuran kecil, maka dibutuhkan adanya pedagang perantara yang bertugas mengumpulkan produk sehingga skalanya menjadi ekonomis untuk diangkut ke pasar. Pada keadaan ini maka saluran pemasaran cenderung panjang.

d) Posisi keuangan pengusaha; produsen yang memiliki posisi keuangan yang kuat cenderung akan memperpendek saluran pemasaran.

Panjang-pendeknya saluran pemasaran juga ditentukan oleh pasar tujuan produk perikanan. Pasar tujuan produk perikanan meliputi 4 jenis pasar yaitu pasar lokal, pasar regional dalam provinsi, pasar nasional dan pasar internasional atau pasar ekspor. Saluran pemasaran untuk pasar lokal memiliki saluran pemasaran yang lebih pendek dibanding untuk pasar regional dan pasar nasional (Effendi dan Oktariza, 2006).

\section{Lembaga dan saluran pemasaran ikan bandeng}

Lembaga yang terlibat dalam pemasaran ikan bandeng dari Kabupaten Indramayu ke pasar DKI Jakarta terdiri dari pembudidaya bandeng sebagai produsen, pedagang pengumpul lokal, pedagang pengumpul besar, pedagang grosir, dan pedagang pengecer. Ikan bandeng dari daerah ini juga tidak hanya dijual segar, tetapi ada juga yang dijual ke pengolahan bandeng tanpa duri dan perusahaan katering. Dari hasil wawancara dengan pedagang pengumpul di Indramayu dan pedagang besar di Pasar Muara Baru diketahui bahwa ikan bandeng dari Indramayu didistribusikan ke banyak daerah. Distribusi pemasaran ikan bandeng dari daerah ini disajikan pada Gambar 1. 


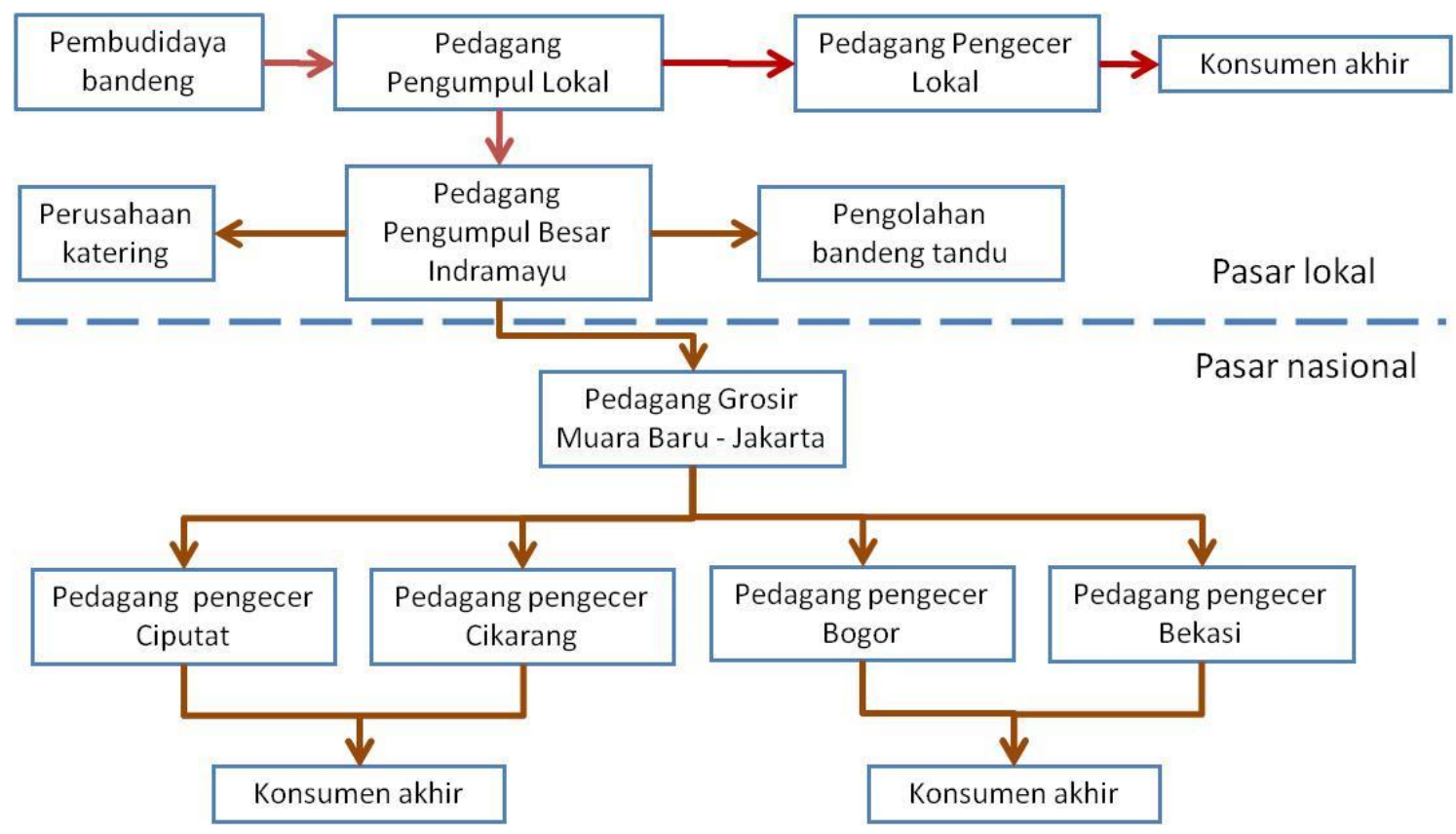

Gambar 1. Saluran pemasaran ikan bandeng dari Kabupaten Indramayu

Dari Gambar 1 terlihat bahwa ikan bandeng yang berasal dari Indramayu maupun daerah lainnya dari Pasar Ikan Muara Baru didistribusikan ke berbagai daerah yang ada di Jabodetabek seperti ke Bekasi, Bogor, Cikarang dan Ciputat.

\section{Lembaga dan saluran pemasaran ikan tongkol}

Lembaga yang terlibat dalam pemasaran ikan tongkol dari Pelabuhan Ratu - Kabupaten Sukabumi ke pasar DKI Jakarta terdiri dari nelayan sebagai produsen, pedagang pengumpul lokal, pedagang pengumpul besar, pedagang besar, dan pedagang pengecer. Dari hasil wawancara dengan pedagang pengumpul di Pelabuhan Ratu dan pedagang besar di Pasar Muara Baru diketahui bahwa ikan tongkol dari daerah ini didistribusikan ke banyak daerah. Distribusi ikan tongkol dari Pelabuhan Ratu mencakup daerah di dalam Kabupaten Sukabumi, Kota Sukabumi, Kabupaten Bogor, Kota Bogor, Jakarta dan beberapa daerah lainnya di Jawa Barat dan Banten. Distribusi pemasaran ikan tongkol dari daerah ini disajikan pada Gambar 2. Ikan tongkol dari daerah ini juga tidak hanya dijual segar, tetapi ada juga yang dijual ke pengolahan ikan pindang yang ada di sekitar Pelabuhan Ratu.

Berdasar Gambar 1 dan Gambar 2 diketahui bahwa Pasar Ikan Muara Baru memiliki fungsi sentral dalam pemasaran ikan bandeng, ikan tongkol dan banyak jenis ikan lainnya yaitu :

1. Sebagai tempat terjadinya proses konsentrasi ikan bandeng dan ikan lainnya dari berbagai daerah produksi;

2. Sebagai tempat terjadinya proses equalisasi atau penyeimbangan antara pasokan dengan permintaan ikan bandeng dan ikan lainnya sehingga tercipta harga keseimbangan dari proses tersebut. 
3. Sebagai tempat terjadinya proses distribusi ikan bandeng dan ikan lainnya menuju berbagai daerah konsumsi yang ada di Jabodetabek serta daerah lainnnya seperti Cilegon, Bandung, Karawang dan lain-lain.

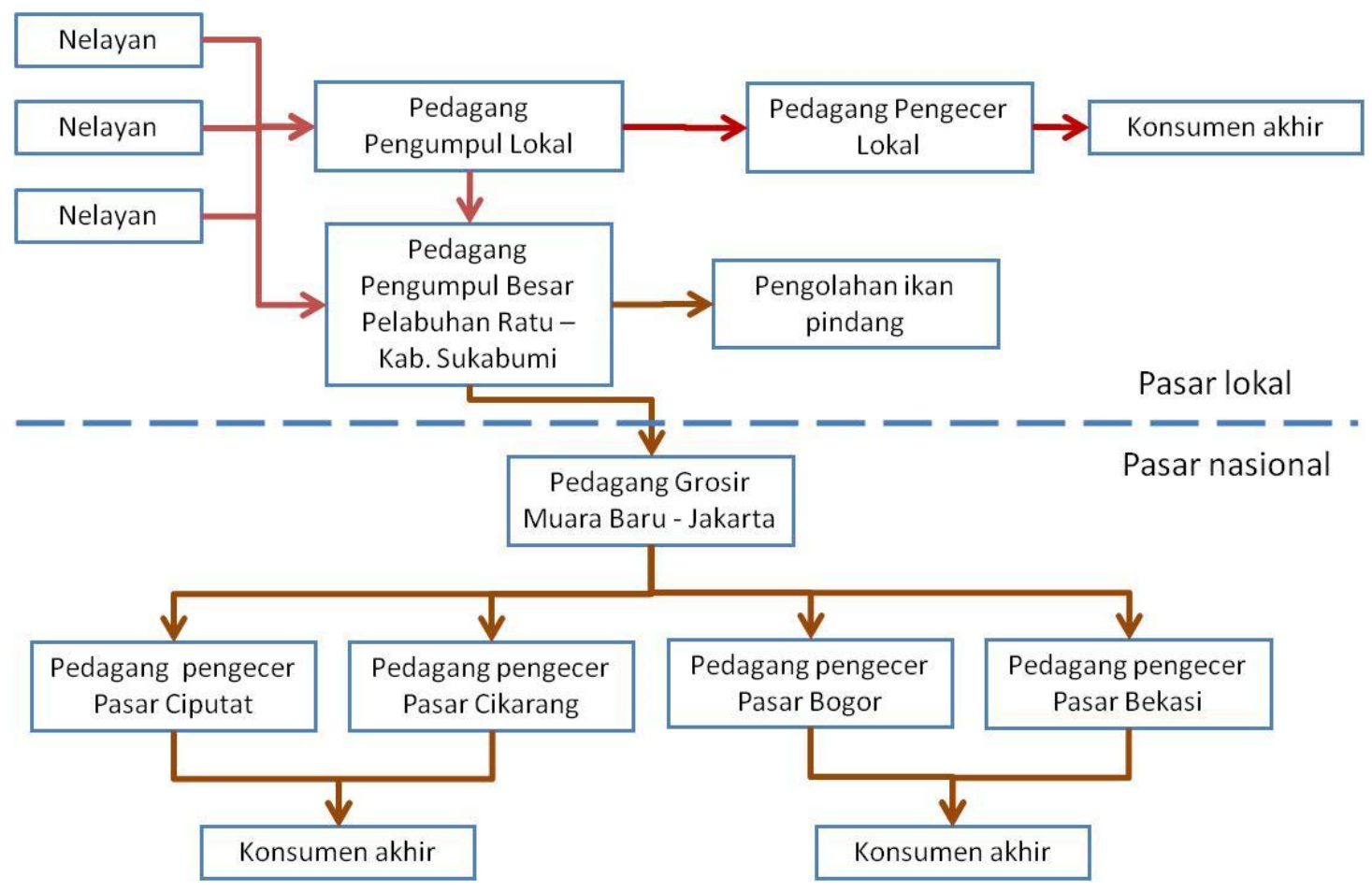

Gambar 2. Saluran pemasaran ikan tongkol dari Pelabuhan Ratu - Sukabumi

Distribusi ke daerah-daerah tujuan akhir dilakukan oleh para pedagang pengecer yang berasal dari masing-masing pasar tersebut. Para pedagang pengecer tersebut membeli beberapa jenis ikan lainnya selain bandeng. Para pedagang pengecer menyewa kendaraan secara berkelompok dari tempat asal, hal ini ditujukan untuk menekan biaya transportasi sehingga menjadi lebih murah.

\section{Biaya, keuntungan dan marjin pemasaran}

Jenis biaya pemasaran dan besaran biaya pemasaran antara pelaku pemasaran ikan bandeng dari Kabupaten Indramayu berbeda. Biaya yang dikeluarkan oleh pedagang pengumpul lokal dalam pemasaran ikan bandeng dari Indramayu terdiri dari biaya transportasi, es, dan upah tenaga kerja. Total biaya pemasaran yang dikeluarkan Rp 1100 per kg. Biaya yang terbesar yaitu biaya transportasi berkisar antara 45,45 - 51,22\% dari total biaya pemasaran. Hal ini sesuai dengan peran yang besar dalam hal distribusi ikan dari lokasi produsen ke daerah pemasaran dari pedagang pengumpul.

Pedagang pengumpul besar dari Indramayu yang memasarkan bandeng ke Pasar Ikan Muara Baru mengeluarkan biaya pemasaran yang cukup besar dengan total biaya Rp 1525 per kg. Biaya pemasaran terdiri dari biaya transportasi, es, upah tenaga kerja, biaya pengawalan. Biaya pengawalan merupakan biaya yang harus dibayarkan oleh pedagang dari daerah yang memasok ikan ke Pasar Ikan Muara Baru. Biaya ini 
dikeluarkan agar ikan milik pedagang dari daerah diketahui kepada siapa yang mengambil atau membelinya sehingga memudahkan penagihan untuk pembayarannya.

Biaya yang dikeluarkan oleh pedagang pengumpul besar di Pelabuhan Ratu dalam pemasaran ikan tongkol terdiri dari biaya transportasi, es, upah tenaga kerja dan biaya pengawalan. Biaya yang terbesar yaitu biaya transportasi berkisar antara 30,45-40,22\% dari total biaya pemasaran. Biaya pengawalan mencapai $19,80 \%$ dari total biaya pemasaran. Hal ini sesuai dengan peran yang besar dalam hal distribusi ikan dari lokasi produsen ke daerah pemasaran dari pedagang pengumpul.

Jenis biaya pemasaran yang dikeluarkan oleh pedagang grosir di Pasar Ikan Muara Baru Jakarta untuk ikan tongkol dan ikan bandeng sama dengan untuk ikan lainnya. Biaya tersebut terdiri dari sewa lapak, listrik, kebersihan, keamanan, uang meja, uang kursi, uang timbangan, es, air dan garam. Total biaya pemasaran pedagang besar mencapai $\mathrm{Rp} 618$ per $\mathrm{kg}$. Biaya pemasaran yang nilai besar diantaranya es (40\%), air dan garam (35,55\%), dan upah angkut (16,17\%).

Pedagang pengecer ikan bandeng dan ikan tongkol di Pasar Ciputat - Jakarta yang membeli ikan dari Pasar Ikan Muara Baru mengeluarkan biaya pemasaran Rp 1497 per $\mathrm{kg}$ ikan. Rincian penggunaan biaya terdiri dari biaya plastik/kemasan 23\%, tranportasi $22 \%$, es $17 \%$, upah angkut $11 \%$, uang tunggu $11 \%$, sisanya untuk biaya kebesihan, keamanan, listrik, air dan sewa lapak. Uang tunggu merupakan biaya yang harus dikeluarkan oleh pedagang pengecer yang peruntukannya sebagai biaya keamanan ketika menyimpan ikan sebelum diangkut ke mobil.

Tabel 1. Margin dan keuntungan pemasaran ikan bandeng dan ikan tongkol menurut lembaga pemasaran

\begin{tabular}{lcccc}
\hline Lembaga pemasaran & \multicolumn{2}{c}{ Ikan bandeng } & \multicolumn{2}{c}{ Ikan tongkol } \\
& $\begin{array}{c}\text { Margin } \\
(\mathrm{Rp} / \mathrm{kg})\end{array}$ & $\begin{array}{c}\text { Keuntungan } \\
(\mathrm{Rp} / \mathrm{kg})\end{array}$ & $\begin{array}{c}\text { Margin } \\
(\mathrm{Rp} / \mathrm{kg})\end{array}$ & $\begin{array}{c}\text { Keuntungan } \\
(\mathrm{Rp} / \mathrm{kg})\end{array}$ \\
\hline Pedagang pengumpul lokal & 1500 & 400 & - & - \\
Pedagang pengumpul besar & 2500 & 975 & 4500 & 1975 \\
Pedagang grosir & 4500 & 3882 & 5500 & 4882 \\
Pedagang pengecer & 5000 & 3503 & 6000 & 4503 \\
\hline Jumlah & 13500 & 8760 & 16000 & 10376 \\
\hline
\end{tabular}

Pada komoditas ikan bandeng dari Tabel 1 terlihat pedagang pengecer memperoleh margin paling besar yaitu Rp 5000 per $\mathrm{kg}$, pedagang besar memperoleh margin Rp 4500 per kg. Pedagang pengumpul lokal dan pedagang pengumpul besar di Kabupaten Indramayu memperoleh marjin masing-masing Rp 1 500/kg dan Rp 2 000/kg. Total margin pemasaran ikan bandeng dari Indramayu ke Jakarta yaitu Rp 13500 per kg. Nilai margin tersebut mencapai $81,8 \%$ dari harga ikan ditingkat pembudidaya bandeng.

Komoditas ikan tongkol dari Tabel 1 terlihat bahwa pedagang pengecer di pasar Ciputat memperoleh margin paling besar yaitu Rp 6000 per kg, pedagang grosir di pasar ikan Muara Baru memperoleh margin Rp 5500 per kg. Pedagang pengumpul di Pelabuhan Ratu memperoleh marjin masing-masing Rp 4500 per kg. Total margin pemasaran ikan tongkol dari Pelabuhan Ratu ke Jakarta yaitu Rp 16000 per kg atau setara dengan harga ditingkat nelayan. Nilai margin tersebut mencapai $100 \%$ dari harga 
ikan tongkol ditingkat nelayan. Distribusi margin tersebut sesuai dengan penelitian Gonarsyah (1992) yang menemukan bahwa pedagang grosir hortikultura di pasar DKI merupakan penerima margin keuntungan yang terbesar diantara para pelaku pemasaran komoditi tersebut.

Biaya pemasaran, menurut Soekartawi (2002), adalah biaya yang dikeluarkan untuk keperluan pemasaran, meliputi biaya pengangkutan, biaya sortir, biaya pengemasan, dan biaya tenaga kerja yang digunakan. Makin efisien pemasaran yang dilakukan, makin kecil biaya pemasaran yang dikeluarkan. Besarnya biaya pemasaran berbeda satu sama lain disebabkan oleh : a) jenis komoditas; b) lokasi pemasaran; c) jenis lembaga pemasaran; dan d) efektivitas pemasaran yang dilakukan. Dari Tabel 2 terlihat bahwa pemasaran ikan tongkol dan bandeng di pasar DKI Jakarta termasuk dalam kategori efisien karena total biaya pemasaran dibagi harga ditingkat konsumen akhir nilainya dibawah 33\%. Biaya pemasaran ikan tongkol dari Pelabuhan Ratu lebih rendah dari ikan bandeng dari Indramayu, sehingga secara relatif dapat dikatakan pemasaran ikan tongkol lebih efisien.

Dari Tabel 2 juga terlihat bahwa pedagang grosir di Pasar Ikan Muara Baru efisiensi pemasarannya lebih tinggi dibandingkan pelaku pemasaran lainnya, baik untuk komoditas bandeng maupun tongkol, karena biaya pemasarannya yang paling rendah. Hal ini karena pedagang grosir tidak mengeluarkan biaya pengangkutan, sedang ketiga pelaku pemasaran lainnya harus mengeluarkan biaya pengangkutan.

Tabel 2. Biaya pemasaran dan efisiensi pemasaran ikan bandeng dan tongkol menurut lembaga pemasaran

\begin{tabular}{lcccc}
\hline Lembaga pemasaran & \multicolumn{2}{c}{ Ikan bandeng } & \multicolumn{2}{c}{ Ikan tongkol } \\
\cline { 2 - 5 } & $\begin{array}{c}\text { Biaya } \\
\text { Pemasaran } \\
(\mathrm{Rp} / \mathrm{kg})\end{array}$ & $\begin{array}{c}\text { Efisiensi } \\
\text { Pemasaran } \\
(\%)\end{array}$ & $\begin{array}{c}\text { Biaya } \\
\text { Pemasaran } \\
(\mathrm{Rp} / \mathrm{kg})\end{array}$ & $\begin{array}{c}\text { Efisiensi } \\
\text { Pemasaran } \\
(\%)\end{array}$ \\
\hline $\begin{array}{l}\text { Pedagang pengumpul lokal } \\
\text { Pedagang pengumpul }\end{array}$ & 1100 & 3,67 & - & - \\
besar & 1525 & 5,08 & 2525 & 7,89 \\
$\begin{array}{l}\text { Pedagang grosir } \\
\text { Pedagang pengecer }\end{array}$ & 618 & 2,06 & 618 & 1,93 \\
\hline Jumlah & 1497 & 4,99 & 1497 & 4,68 \\
\hline
\end{tabular}

Efisiensi pemasaran juga diketahui dengan melihat rasio keuntungan-biaya pemasaran yang diperoleh masing-masing lembaga pemasaran. Semakin merata nilai rasio keuntungan terhadap biaya pemasaran, maka secara teknis (operasional) sistim pemasaran tersebut semakin efisien (Limbong dan Sitorus 1987). Nilai rasio keuntunganbiaya pemasaran, baik untuk ikan bandeng maupun ikan tongkol, terlihat tidak merata diantara para pelaku pemasaran seperti disajikan pada Tabel 3. Pedagang grosir dan pedagang pengecer memiliki nilai rasio yang sangat besar, sedang pedagang pengumpul lokal dan pedagang pengumpul besar memiliki nilai rasio dibawah $100 \%$. Hal ini menunjukan bahwa pemasaran kedua komoditas tersebut belum efisien karena menurut Mubyarto (1989) sistem pemasaran dianggap efisien apabila memenuhi dua syarat yaitu : 
1) Mampu menyampaikan hasil-hasil dari petani dengan produsen kepada konsumen dengan biaya serendah mungkin.

2) Mampu mengadakan pembagian yang adil dari keseluruhan harga yang dibayar konsumen akhir kepada semua pihak yang telah ikut serta dalam kegiatan produksi dan pemasaran komoditas tersebut.

Tabel 3. Rasio keuntungan-biaya pemasaran ikan bandeng dan tongkol menurut lembaga pemasaran

\begin{tabular}{lcc}
\hline \multirow{2}{*}{ Lembaga pemasaran } & \multicolumn{2}{c}{ Rasio keuntungan-biaya pemasaran (\%) } \\
\cline { 2 - 3 } & Ikan bandeng & Ikan tongkol \\
\hline Pedagang pengumpul lokal & 36,36 & - \\
Pedagang pengumpul besar & 63,93 & 78,22 \\
Pedagang grosir & 628,16 & 789,97 \\
Pedagang pengecer & 234,00 & 300,80 \\
\hline
\end{tabular}

Dalam pemasaran ikan ke Jakarta pembudidaya bandeng Indramayu memperoleh farmer's share sebesar 55\%, sedang nelayan ikan tongkol Pelabuhan Ratu memperoleh fisherman's share sebesar 50\%. Farmer's/fisherman's share dapat dijadikan sebagai tolok ukur efisiensi pemasaran, dimana semakin tinggi nilainya maka semakin efisien kegiatan pemasaran. Dari Tabel 3 terlihat bahwa pemasaran ikan bandeng lebih efisien dibanding ikan tongkol karena nilai farmer's share lebih tinggi. Berdasar Tabel 1 dan Tabel 3 juga terlihat bahwa farmer's share atau fisherman's share berhubungan negatif dengan marjin pemasaran, dimana semakin tinggi marjin pemasaran maka bagian produsen (farmer's share atau fisherman's share) akan semakin rendah.

Tabel 3. Farmer's/fisherman's share pemasaran ikan bandeng dan ikan tongkol

\begin{tabular}{|c|c|c|}
\hline Uraian & Ikan bandeng & Ikan tongkol \\
\hline $\begin{array}{lll}\text { Harga } & \text { ditingkat } & \text { nelayan/pembudidaya } \\
(\mathrm{Rp} / \mathrm{kg}) & & \end{array}$ & 16500 & 16000 \\
\hline Harga ditingkat pedagang pengecer $(\mathrm{Rp} / \mathrm{kg})$ & 30000 & 32000 \\
\hline Farmer's/Fisherman's share (\%) & 55.00 & 50.00 \\
\hline
\end{tabular}

Pembelian dan penjualan ikan bandeng oleh pelaku pemasaran di Kabupaten Indramayu dilakukan secara tunai, baik pembelian dari pembudidaya maupun dari pedagang pengumpul lokal. Pedagang pengumpul besar dari Indramayu menjual ikan bandeng kepada pedagang grosir di Pasar Ikan Muara Baru dengan sistem konsinyasi. Penetapan harga akan dilakukan setelah ikan bandeng laku terjual kepada para pedagang pengecer. Penentuan harga di ditetapkan oleh pedagang grosir. Dengan sistim konsinyasi ini tidak jarang pedagang pengumpul dari daerah mengalami kerugian. Hal ini akan terjadi ketika harga ikan mengalami penurunan karena kelebihan pasokan. Sementara pedagang pengumpul di daerah sudah membeli ikan tersebut dari pembudidaya ikan atau pedagang pengumpul dengan harga yang sudah ditetapkan. Dengan demikian hubungan antara harga, produksi dan pemasaran mempunyai kaitan yang erat, dimana petani/nelayan sebagai produsen dan lembaga pemasaran dengan masing-masing fungsi pemasarannya mempunyai peranan yang menentukan dan saling mempengaruhi (Setyawati et al. 1990). 


\section{Isu Pemasaran Hasil Perikanan}

Dari hasil kajian ditemukan beberapa temuan menarik yang merupakan isu pemasaran hasil perikanan, baik untuk komoditas ikan budidaya maupun komoditas hasil tangkapan. Secara umum dalam melakukan penjualan hasil perikanan para pelaku usaha pemasaran yang terdiri dari pedagang pengumpul lokal, pedagang pengumpul antar kota, pedagang grosir dan pedagang pengecer mengeluarkan biaya pemasaran yang terdiri dari: biaya transportasi, biaya es (untuk penjualan ikan segar) atau biaya oksigen (untuk penjualan ikan hidup), upah tenaga kerja, biaya kemasan, biaya kebersihan dan keamanan, serta air. Biaya-biaya tersebut merupakan biaya yang memang seharusnya dikeluarkan karena berpengaruh langsung terhadap ikan yang dijual atau ada juga yang merupakan biaya resmi karena dipungut secara legal.

Dalam prakteknya para pelaku pemasaran hasil perikanan seringkali harus mengeluarkan biaya pemasaran tambahan. Berikut ini diuraikan beberapa biaya pemasaran tambahan yang harus dikeluarkan oleh para pedagang komoditas perikanan khususnya tongkol dan bandeng yang dipasarkan antar kota melalui Pasar Ikan Muara Baru - Jakarta.

Pedagang pengumpul antar kota dari Pelabuhan Ratu dan Indramayu harus mengeluarkan biaya tambahan yang disebut sebagai "biaya pengawalan". Biaya tersebut dibayarkan kepada orang yang diberi kepercayaan oleh pedagang pengumpul antar kota untuk menjaga agar ikan yang dikirimkan sampai kepada pedagang grosir di Pasar Ikan Muara Baru. Besarnya biaya tersebut Rp 30000 per blonk (kapasitas isi ikan $70 \mathrm{~kg} /$ blonk) atau Rp 60000 per fiber (kapasitas isi ikan 100-120 kg/fiber). Sehingga jika dihitung per $\mathrm{kg}$ maka biaya tersebut berkisar antara Rp $429-600$ per kg. Hal ini berarti harga ikan tongkol atau ikan bandeng yang dibeli oleh konsumen harganya menjadi lebih mahal antara Rp 429 - 600 per kg karena biaya tersebut pada akhirnya akan menjadi beban konsumen akhir. Bagi para pedagang pengumpul antar kota biaya tersebut berkisar 20$33 \%$ dari total biaya pemasaran per $\mathrm{kg}$. Jika melihat kepada sistim pengangkutan yang berlaku umum, seharusnya biaya transportasi yang dikeluarkan oleh pengirim barang sudah termasuk "biaya pengawalan" tersebut karena barang pasti akan diterima utuh oleh penerima barang dengan membayar biaya transportasi atau biaya pengiriman (jika menggunakan paket).

Para pedagang grosir yang berjualan di Pasar Ikan Muara Baru - Jakarta juga mengeluarkan tiga jenis biaya tambahan. Biaya tambahan dikeluarkan yaitu uang meja ( $\mathrm{Rp} 0.67$ per $\mathrm{kg}$ atau $0.11 \%$ dari biaya pemasaran), uang kursi ( $\mathrm{Rp} 0.67$ per $\mathrm{kg}$ atau $0.11 \%$ dari biaya pemasaran), dan uang timbangan (Rp 3.33 per $\mathrm{kg}$ atau $0.54 \%$ ), sehingga total biaya tambahan sebesar Rp 4.67 per kg. Pedagang grosir di Pasar Ikan Muara Baru juga harus mengeluarkan upah biaya angkut ikan dari tempat parkir ke lapak tempat berjualan sebesar Rp 100 per $\mathrm{kg}$ atau $16.17 \%$ dari total biaya pemasaran, biaya tersebut cukup mahal karena jarak angkutnya yang sangat dekat saja. Sebagai pembanding biaya angkut dari Indramayu ke Pasar Ikan Muara baru yang jaraknya sangat jauh hanya Rp 525 per kg ikan.

Pedagang pengecer ikan yang membeli ikan di Pasar Ikan Muara Baru Jakarta juga mengeluarkan biaya tambahan. Jenis biaya tambahan yang dikeluarkan yaitu disebut "uang tunggu" karena biasanya setelah membeli ikan pada satu pedagang grosir, maka 
pedagang pengecer tersebut akan membeli ikan lainnya pada pedagang grosir lainnya sehingga ikan yang sudah dibelinya tersebut harus dititipkan pada satu lokasi. Penitipan ikan tersebut dikenai uang tunggu. Besarnya uang tunggu yang harus dibayarkan yaitu Rp 20000 per hari. Biasanya seorang pedagang pengecer membeli ikan per hari antara $120-240 \mathrm{~kg}$. Sehingga biaya uang tunggu antara Rp $83-167$ per $\mathrm{kg}$. Biaya ini tentunya akan berlaku sama dengan "biaya pengawalan" yaitu akan dibebankan kepada konsumen akhir, sehingga artinya konsumen akhir akan membeli ikan lebih mahal antara Rp 83 - 167 per kg.

\section{Pengembangan Kebijakan Pemasaran}

Sistim agribisnis komoditas perikanan, baik komoditas budidaya perikanan maupun komoditas perikanan tangkap, masih dilakukan terpisah. Integrasi fungsional antara daerah produksi dengan pasar perikanan seperti Jakarta dan daerah sekitarnya masih sangat terbatas. Hal ini terlihat dari sering terjadinya ketidakseimbangan dalam proses distribusi komoditas perikanan ke pasar tujuan. Akibat ketidakseimbangan proses distribusi tersebut tercermin pada volatilitas harga antar waktu yang tinggi pada komoditas perikanan. Menurut Irawan et al. (2001) ada 3 faktor utama yang menyebabkan struktur agribisnis menjadi tersekat-sekat dan kurang memiliki daya saing yaitu: 1) tidak ada keterkaitan fungsional yang harmonis antara setiap kegiatan atau pelaku agribisnis; 2) terbentuknya margin ganda sehingga ongkos produksi, pengolahan dan pemasaran hasil yang harus dibayar konsumen menjadi lebih mahal karena sistem agribisnis yang tidak efisien; dan 3) tidak adanya kesetaraan posisi tawar antara petani dengan pelaku agribisnis lainnya sehingga petani sulit mendapat harga pasar yang wajar. Integrasi fungsional antara sentra produksi perikanan budidaya dan perikanan tangkap dengan pasar perikanan juga harus didukung dengan regulasi untuk memberikan perlindungan kepada nelayan dan pembudidaya ikan, serta pedagang perantara yang terlibat dalam pemasaran.

Regulasi yang terkait dengan penetapan harga komoditas maupun distribusinya dapat dijadikan instrumen oleh pemerintah untuk melindungi para nelayan dan pembudidaya ikan dan serta pedagang perantara ikan. Sebagai contoh integrasi sentra produsen dan pasar perikanan yang telah berjalan dengan baik yaitu di Jepang. Kepentingan produsen komoditas pertanian, termasuk perikanan, di Jepang dilindungi oleh Undang-undang Pasar Grosir Sentral. UU tersebut ditetapkan pada tahun 1923 dan karena pe(rubahan sosial yang terjadi kemudian direvisi pada tahun 1971 (Pudjiatmoko 2007). Pasar grosir sentral di Jepang bertanggungjawab menjadi penghubung antara produsen dengan pedagang pengecer. Fungsi pasar grosir sentral di Jepang meliputi :

1. Pengumpulan beragam produk segar dalam jumlah banyak dari dalam dan luar negeri;

2. Penentuan harga yang adil, karena harga akan mengacu kepada hasil lelang sebagaimana diatur dalam perundangan. Harga ditentukan secara wajar karena merupakan harga tertinggi yang diajukan oleh penawar yang menggambarkan supply and demand produk yang bersangkutan pada hari tersebut;

3. Distribusi dari produk-produk yang telah terkumpul ke dalam jumlah dan ukuran yang lebih kecil untuk dijual kepada beberapa stock purchasers. 
4. Pengembangan akuntansi yang sehat melalui pembayaran yang harus dilakukan sesegera mungkin sesuai dengan peraturan yang telah ditetapkan;

5. Pengurangan biaya distribusi dengan pembelian dan penjualan beberapa produk dalam jumlah besar di satu tempat. Biaya transportasi dan biaya-biaya lain terkait distribusi dapat dikurangi;

6. Penyediaan informasi terkini (prompt information) untuk menghindari kebingungan tentang jenis dan jumlah produk pertanian dan produk perikanan yang dijual di pasar, serta harga grosir pada hari tersebut.

Komisi bagi wholesaler di pasar grosir Jepang telah diatur dalam ordonansi atau peraturan pemerintah daerah. Komisi untuk komoditas perikanan sebesar 5.5\%, komoditas sayuran $8.5 \%$, komoditas buah-buahan $7.0 \%$, komoditas daging $3.5 \%$, serta komoditas bunga dan tanaman hias $9.5 \%$. Wholesaler di pasar harus mendapatkan izin dari Menteri Pertanian, Kehutanan dan Perikanan (Pudjiatmoko 2007).

Dalam rangka menciptakan integrasi fungsional antara sentra produksi komoditas perikanan tangkap dan perikanan budidaya dengan daerah sentra konsumsi seperti Jakarta perlu dilakukan beberapa strategi kebijakan berikut :

1. Penyediaan informasi pasar yang terpadu antara sentra pemasaran seperti Pasar Ikan Muara Baru dengan berbagai sentra produksi perikanan budidaya dan perikanan tangkap. Penyediaan informasi terutama tentang harga dan perkiraan pasokan yang real-time dan selalu di-update akan sangat berguna bagi para pelaku pemasaran baik yang berada di sentra produksi perikanan budidaya/perikanan tangkap maupun di sentra konsumsi.

2. Revitalisasi sistem penjualan dengan lelang (auction) di sentra produksi, baik untuk komoditas hasil perikanan tangkap maupun perikanan budidaya. Saat ini banyak kegiatan penjualan ikan pada sentra produksi perikanan tangkap yang sudah tidak menggunakan sistem lelang lagi. Penjualan sistim lelang juga dapat dilakukan pada sentra konsumsi seperti di pasar ikan Muara Baru atau pasar ikan Muara Angke, terutama untuk jenis-jenis ikan tertentu yang banyak dari sisi volume penjualan.

3. Penyediaan infrastruktur pemasaran khususnya sub terminal agribisnis dan cold storage baik di sentra produksi maupun di sentra pemasaran dengan fasilitas yang memadai. Pemanfaatan sub terminal agribisnis tersebut agar optimal tidak hanya digunakan untuk perdagangan komoditas perikanan saja, tetapi bisa juga untuk komoditas pertanian atau peternakan. Oleh karena itu pemilihan lokasinya juga harus dipertimbangkan secara tepat.

4. Penyediaan prasarana pendukung yang memadai seperti jalan raya, kendaraan berpendingin, alat komunikasi,dan lain-lain yang menghubungkan antara sentra produksi perikanan dengan sentra konsumsi. Hal ini penting dilakukan untuk menghemat waktu pengangkutan, menjaga kualitas ikan supaya tetap baik sampai di tangan konsumen akhir.

5. Penetapan harga dasar atau harga patokan untuk beberapa jenis ikan yang memiliki share besar terhadap produksi dan konsumsi di masyarakat. Ada penetapan harga dasar atau harga patokan ini akan memberikan rasa aman bagi para pelaku usaha dan pelaku pemasaran serta juga bagi konsumen guna menjada volatilitas harga yang tinggi. 
6. Penetapan batasan margin yang boleh diambil oleh para pelaku pemasaran hasil perikanan ikan seperti yang diberlakukan di Jepang.

\section{SIMPULAN}

Saluran pemasaran baik komoditas ikan bandeng dan ikan tongkol secara umum relatif sama. Saluran pemasaran kedua jenis komoditas tersebut melibatkan lembaga pemasaran yatu nelayan atau pembudidaya, pedagang pengumpul lokal, pedagang pengumpul besar (yang memasarkan antar kota), pedagang grosir di pasar Ikan Muara Baru, pedagang pengecer yang berasal dari berbagai kota di seputar Jabodetabek dan sekitarnya.

Pemasaran ikan bandeng dan ikan tongkol ke pasar DKI Jakarta jika hanya melihat aspek biaya pemasaran yang dikeluarkan oleh pelaku pemasaran sudah efisien karena biaya pemasarannya relatif rendah dibanding harga ditingkat konsumen akhir. Namun jika melihat rasio keuntungan-biaya pemasaran yang diterima oleh masingmasing pelaku pemasaran maka pemasaran kedua komoditas tersebut belum efisien karena belum bisa mengadakan pembagian yang adil dari keseluruhan harga yang dibayar konsumen akhir kepada produsen dan pedagang perantara yang terlibat dalam kegiatan produksi dan pemasaran komoditas tersebut.

Para pedagang perantara mengeluarkan biaya pemasaran tambahan selain biaya yang umumnya berlaku. Pedagang pengumpul besar mengeluarkan biaya tambahan yaitu biaya pengawalan antara Rp 429 - 600 per kg. Pedagang grosir mengeluarkan biaya tambahan yang terdiri dari uang meja dan uang kursi masing-masing Rp 0.67 per kg serta uang timbangan Rp 3.33 per kg. Pedagang pengecer mengeluarkan biaya tambahan uang tunggu antara Rp 83 - 167 per kg. Pengeluaran biaya tambahan ini pada akhirnya akan dibebankan kepada konsumen akhir.

Perlu adanya regulasi untuk melindungi kepentingan pembudidaya ikan, nelayan dan konsumen dalam pemasaran komoditas perikanan. Regulasi seperti UU Pasar Grosir Sentral yang ditetapkan di Jepang perlu dipertimbangkan untuk dibuat di Indonesia. Regulasi ini tidak hanya untuk komoditas perikanan saja tetapi juga mencakup komoditas pertanian dan peternakan.

\section{DAFTAR PUSTAKA}

Effendi I dan W Oktariza. 2006. Manajemen Agribisnis Perikanan. PT Penebar Swadaya. Jakarta.

Gonarsyah, Isang. 1992. Peranan Pasar Induk Kramat Jati Sebagai Barometer Harga Sayur Mayur di Wilayah DKI Jakarta. Mimbar Sosek,Institut Pertanian Bogor. Bogor. (5):43-48.

Hanafiah A M, dan A M Saefudin. 1986. Tataniaga Hasil Perikanan. Cetakan Pertama. Universitas Indonesia. Jakarta.

Irawan B, Nurmanaf R, Hastuti EL, Muslim C, dan Y Darwis V. 2001. Kebijakan pengembangan agribisnis komoditas unggulan hortikultura. Pusat Penelitian dan Pengembangan Sosial Ekonomi Pertanian. Badan Penelitian dan Pengembangan Pertanian. Bogor.

Limbong W.H., dan P Sitorus. 1987. Pengantar Tataniaga Pertanian. Fakultas Pertanian IPB. Bogor.

Mubyarto. 1989. Pengantar Ekonomi Pertanian. LP3ES. Jakarta. 
Nazir M. 2003. Metode Penelitian. Penerbit Salemba Empat. Jakarta.

Pudjiatmoko. 2007. Studi Banding Pasar Ikan Tokyo dan Osaka 17-20 Juli 2006. Jurnal Atani Tokyo.

Setyawati T, Suhandoko, Trisulo W, dan M Rais. 1990. Tataniaga Pisang Batu dan Pisang Buah di Sentra Produksi Sumatera Barat. Bull. Pel. Hort. 5 (1) : 59 - 65.

Soekartawi. 2002. Agribisnis - Teori dan Aplikasinya. PT Raja Grafindo Persada. Jakarta.

Sudiyono. 2001. Pemasaran Pertanian. Universitas Muhamadiyah Malang. Malang.

Supranto J. 1977. Statistik teori dan aplikasi. Jakarta. Erlangga. 